\title{
Development and Operational Test of the Free Semester Program Education in Arboreta and Botanical Gardens: Focusing on 'Gardener for a Day' Program in Korea National Arboretum
}

\author{
Do-Lee Yun and Mi-Jeong Yoon ${ }^{*}$ \\ Gardens and Education Division, Korea National Arboretum, Pocheon 11186, Korea
}

\begin{abstract}
As part of the free semester program, the 'Gardener for a day' program in the Korea National Arboretum was newly developed in 2018. The program was developed as a free semester program reflecting the works of a 'gardener' who performs the planning, preparation, maintenance and management of exhibition gardens. This 'Gardener for a day' program was applied to a total of 106 middle school students in October 2018. Educational elements were extracted from Korea National Arboretum exhibition gardens and career exploration of gardeners. The program was designed to provide education on theory and practices, including watching the gardener video, visiting the gardener booth, meeting with actual gardeners at Korea National Arboretum, visiting two exhibition gardens, and participating in three types of practical training as a gardener. A survey about program satisfaction and education was conducted after the program to analyze the students' satisfaction with the program (contents, management, instructor), free semester program (career planning, occupational attitude, independence), and education (awareness of forest biospecies, preservation will). The analysis showed that the following results: satisfaction with the program (score 4.0), free semester program (score 3.8), and education (score 4.0). Comparative analysis of the pretestposttest questionnaires showed that there were significant educational effects in career planning, occupational attitude, and awareness of forest biospecies.
\end{abstract}

Keywords: career experience, gardening, Korea National Arboretum educational program, one-day program

\section{Introduction}

According to the 'Middle School Free Semester Program Action Plan' announced in 2015, the free semester program has been implemented in all middle schools in Korea since 2016 (Korea Educational Development Institute, 2015). As a result, issues have been raised about the limited term, which led to the 'Middle School Free Semester Program Expansion and Development Plan' in 2018, and currently the free semester program for one year (two semesters) is operated in over 1,500 schools in Korea (Kim and Kim, 2018). The 'Free semester program activities' in the free semester program are comprised of four types of activities (career exploration, elective activities, art and sports, club

Received: March 16, 2019, Revised: April 10, 2019, Accepted: May 22, 2019

First author: Do-Lee Yun, E-mail: sug161 @naver.com, (1) https://orcid.org/0000-0001-9200-6220

*Corresponding author: Mi-Jeong Yoon, E-mail: mjyoon75@korea.kr, (i) https://orcid.org/0000-0002-4176-2373 
activities) (Lee, 2018). Career exploration in particular requires specialized programs, human resources and connection to local resources since various career-related experiences are needed. However, there is insufficient social consensus about the system, as well as stable support of the budget and human resources (Lee, 2018). Therefore, it is necessary to build a social infrastructure that can provide active support and provide a specialized free semester education program by a national institution in order to expand and develop the free semester system and secure diversity and expertise of career exploration activities (Yun et al., 2018).

People's view of the forest is constantly changing (Lee et al., 2008). As the national demand for forest services is recently growing in terms of not only leisure but various other fields such as therapy and education, there is a need for policies to provide complex forest environment services combining multiple fields such as experience, therapy and education in addition to just creating recreation forests and forest parks (Seok and Ahn, 2013). According to the '2nd Comprehensive Plan for Forest Education' announced by the Korea Forest Service in 2018, the number of participants in forest education increased by 93\% from 1.71 million in 2013 to 3.3 million in 2017, which shows that the national interest in forest education is continuously increasing (Korea Forest Service, 2018). Accordingly, the Korea Forest Service attempted to expand forest education in schools by operating a related free semester program education in addition to building an educational infrastructure to promote forest education. However, it is still not enough to meet the national demand, and thus it is necessary to continuously build new infrastructures and expand the scope of forest education (Korea Forest Service, 2018).

Korea National Arboretum has been running the 'Botanist for a day' program since 2012 as a career experience program, and then the 'Entomologist for a day' program since 2016 as the free semester program began to be implemented, the purpose of which is to help students directly experience the jobs at Korea National Arboretum and have the chance to explore their career paths. In addition, they are also operating various programs for participants to explore the arboreta and feel closer to the forests by learning the importance of forest creatures, such as the forest school, exploring rare endemic plants, and one-day forest interpreter experience. With the implementation of the free semester program in 2018, the Arboretum Education Center of the Korea National Arboretum is constantly developing various free semester education program.

Arboreta and botanical gardens are facilities that collect, grow, preserve and exhibit plants, and must cultivate plants with records and manage them professionally. Korea National Arboretum has 6,344 species of plants (Korea National Arboretum, 2019), and exhibition and preservation of such plants are considered important duties. The plants are gathered by theme and taxonomic group, and cultivated in the exhibition garden, which is managed by experts and used as research materials through monitoring. To this end, those who perform duties such as collecting, growing, cultivating, exhibiting and recording plants in arboreta and botanical gardens are referred to as 'gardeners' (Korea National Arboretum, 2004; Kim, 2011). Chollipo Arboretum claimed that arboreta need management specialists, or gardeners, with knowledge and expertise about exhibition gardens and plant physiology (Chollipo Arboretum, 2009). However, there is insufficient research on gardeners that are specialized in duties required by arboreta and botanical gardens (Jeong, 2013). This study developed and test-operated a free semester program career experience program for students to directly and indirectly experience the practical affairs of gardeners at arboreta and botanical gardens for specialized career experience, and even promote their awareness in forest biospecies. The research questions are as follows.

First, with what elements will the program be organized for efficient gardener experience?

Second, what educational effects would the program have on participating students? 


\section{Research Methods}

\section{Program development}

This study developed and test-operated a 'Gardener for a day' program at arboreta and botanical gardens in the following order: analyzing and extracting the elements of education related to gardeners, designing and developing the program, test-operating the program and analyzing the statistics. The initial proposal is drawn up under the theme of 'gardener' in four types such as one-day programs ( 2 hours, 4 hours) and multiple-day programs (three-day, five-day) (Table 1), and the one-day program ( 2 hours) was used in test operation. The instructional design of the ADDIE mode 11) was used to develop the program for test operation (Table 2), and the specific details of each step are shown in 'Results and Discussion.'

\section{Selection of education contents related to Korea National Arboretum exhibition gardens}

Korea National Arboretum is managing 25 exhibition gardens in the area of 1,120ha for efficient plant exhibition, and has 3,344 species of plants in the exhibition gardens and 3,000 species of plants in the Tropical plant resources research center. To provide education in the outdoor space of specialized exhibition gardens where the plants are cultivated during the 'Gardener for a day' program, we monitored the exhibition gardens in September 2018 to determine the plant species, plant conditions, circulation of exhibition gardens, and risk factors. The objectives of the 'Gardener for a day' program are as follows: 1) learn about and visit Korea National Arboretum and exhibition gardens, 2) learn about and perform the role of gardeners at Korea National Arboretum exhibition gardens to promote understanding about gardeners, and 3) obtain the opportunity for career exploration as a gardener at Korea National Arboretum (Table 3). The program is test-operated in 2018 and the contents of education are organized based on the exhibition themes of the Rare \& endemic plant garden and Tropical plant resources research center (Tables 3 and 4).

Table 1. Models of educational 'Gardener’ program in Korea National Arboretum

\begin{tabular}{|c|c|c|c|c|}
\hline Category & Program 1 & Program 2 & Program 3 & Program 4 \\
\hline Participants & \multicolumn{4}{|c|}{ Middle school students } \\
\hline Type & One-day & One-day & Three-day & Five-day \\
\hline Place & $\begin{array}{l}\text { Korea National } \\
\text { Arboretum }\end{array}$ & $\begin{array}{l}\text { Korea National } \\
\text { Arboretum }\end{array}$ & $\begin{array}{l}\text { Korea National } \\
\text { Arboretum }\end{array}$ & $\begin{array}{c}\text { Korea National Arboretum } \\
\text { (three days) } \\
\text { and school (two days) }\end{array}$ \\
\hline Total duration & 2 hours & 4 hours & 12 hours & 20 hours \\
\hline Level of difficulty & \multicolumn{2}{|c|}{ General career experience } & \multicolumn{2}{|c|}{ Advanced career experience } \\
\hline \multirow{3}{*}{ General outline } & $\begin{array}{l}\text { Visiting two exhibition } \\
\text { gardens }\end{array}$ & $\begin{array}{l}\text { Visiting three exhibition } \\
\text { gardens }\end{array}$ & $\begin{array}{l}\text { Visiting six exhibition } \\
\text { gardens }\end{array}$ & $\begin{array}{l}\text { Visiting six exhibition } \\
\text { gardens }\end{array}$ \\
\hline & $\begin{array}{l}\text { Participating in } \\
\text { three experiences }\end{array}$ & $\begin{array}{l}\text { Participating in } \\
\text { five experiences }\end{array}$ & $\begin{array}{l}\text { Participating in } \\
\text { nine experiences }\end{array}$ & $\begin{array}{l}\text { Participating in } \\
\text { twelve experiences }\end{array}$ \\
\hline & $\begin{array}{l}40 \text { minute } \\
\text { classroom learning }\end{array}$ & $\begin{array}{l}60 \text { minute } \\
\text { classroom learning }\end{array}$ & $\begin{array}{c}180 \text { minute } \\
\text { classroom learning }\end{array}$ & $\begin{array}{c}300 \text { minute } \\
\text { classroom learning }\end{array}$ \\
\hline
\end{tabular}

1) The ADDIE model is based on the theory by Sels and Richey who classified the instructional design process and elaborated by multiple instructional designers. It establishes the general procedures of developing educational programs and is thus a verified model that is generally applied (Kang, 2013). 
Table 2. ADDIE model of 'Gardener for a day'

ADDIE Details

Analysis Teaching elements extraction

1) Extraction of educational elements for the searching of forest biology in free semester program from a gardener's work

2) Analysis of a gardener's work based on season and exhibition garden characteristics in order to extract educational elements

1) Education types are organized by combining theory and practice for students to experience a gardener's work directly or indirectly

\begin{tabular}{|c|c|c|c|}
\hline & & & \\
\hline & & Type & Elements \\
\hline Design & $\begin{array}{l}\text { Program design } \\
\text { to experience }\end{array}$ & Directly & $\begin{array}{l}\text {-Collecting seeds } \\
\text {-Sowing/planting } \\
\text {-Monitoring plants }\end{array}$ \\
\hline & & & -Viewing a gardener's work video \\
\hline & & Indirectly & -Viewing actual gardener work \\
\hline & & & -Classroom learning using teaching materials \\
\hline & & $\begin{array}{l}\text { 2) Set the program a } \\
\text { the free semester }\end{array}$ & $\begin{array}{l}\text { ort-term course by reflecting the characteristics of } \\
\text { ion program }\end{array}$ \\
\hline & & $\begin{array}{l}\text { 1) Producing a 'garc } \\
\text { National Arboret }\end{array}$ & ideo' that includes the work of gardener of the Korea \\
\hline Development & $\begin{array}{l}\text { Program development } \\
\text { for free semester }\end{array}$ & $\begin{array}{l}\text { 2) Producing a 'gard } \\
\text { the gardening wo }\end{array}$ & $\begin{array}{l}\text { ooth' where participants can view tools and watch } \\
\text { the gardener }\end{array}$ \\
\hline & & $\begin{array}{l}\text { 3) Producing 'learni } \\
\text { Arboretum }\end{array}$ & terials' with educational elements of the Korea National \\
\hline Implementation & Pilot application & Applied to middle sc & students (106 total) \\
\hline Evaluation & Statistical analysis using SPSS & Analysis of program & action in terms of free semester program and education \\
\hline
\end{tabular}

\section{Extraction of educational elements and program planning in terms of gardener career experience in arboreta and botanical gardens}

To come up with educational elements in terms of gardener career experience in arboreta and botanical gardens, details were discussed with field specialists and plant experts. Based on that, we set the scope of the gardener's job at arboreta and botanical gardens to include monitoring for research in addition to forming, maintaining, fixing and managing exhibition gardens. The educational elements in terms of career experience that can be directly and indirectly experienced by students were extracted, considering the level of students as well as the program operation period within the scope of the gardener's job. The program was designed to include watching the 'gardener video', visiting the 'gardener booth', meeting the 'Korea National Arboretum gardener', visiting two specialized exhibition gardens, and participating in three types of practical training as a gardener. Throughout the entire program, the students participated along with an instructor to explain necessary theories, and also used activity sheets as training aids to help them understand (Table 4).

\section{Subjects of test operation}

The participants for the 'Gardener for a day' program were recruited in September 2018, and the program was testoperated twice on students at two middle schools that participated in October 2018 (Table 5). Total 106 valid copies of the questionnaire were used among those from the pretest-posttest survey to analyze the satisfaction in education and educational effects. 
Table 3. Characteristics of 'Gardener for a day' program

Category
\begin{tabular}{ll} 
Participants & Middle school students \\
Type / Duration & One-day / 2 hours \\
\hline Month & October \\
Klace & Korea National Arboretum exhibition gardens \\
(Rare \& endemic plant garden, Tropical plant resources research center)
\end{tabular}
$\begin{array}{ll}\text { 1) Students learn about the Korea National Arboretum and the Korea National Arboretum exhibition } \\
\text { centers and visit the places. } \\
\text { 2) Students learn about a gardener's role in the exhibition gardens and understand a gardener's work } \\
\text { through experience. } \\
\text { 3) Give the opportunity to explore the path of becoming a gardener for the Korea National Arboretum to } \\
\text { students }\end{array}$

Table 4. Contents of the 'Gardener for a day' program

\begin{tabular}{|c|c|c|}
\hline Category & Time & Program contents \\
\hline Introduction & $10: 00$ to $10: 15$ & $\begin{array}{l}\text { 1) Filling out a pre-questionnaire } \\
\text { 2) Watching the 'gardener video' }\end{array}$ \\
\hline Stage 1 & $10: 15$ to $10: 35$ & $\begin{array}{l}\text { 3) Defining the gardener of the Korea National Arboretum } \\
\text { 4) Explaining the work of gardeners of the Korea National Arboretum } \\
\text { 5) Hands-on experience of gardener tools and watching planting steps in a gardener booth }\end{array}$ \\
\hline Stage 2 & $10: 35$ to $11: 05$ & $\begin{array}{l}\text { 6) Meeting the actual gardeners from the Korea National Arboretum and listening to talks about gardening } \\
\text { 7) Learning how to irrigate plants and introduced to the greenhouse environmental measurement device } \\
\text { 'Dotori' } \\
\text { 8) Practice greenhouse environmental measurement }\end{array}$ \\
\hline Stage 3 & $11: 05$ to $11: 25$ & $\begin{array}{l}\text { 9) Monitoring of blossoming flowers in Rare \& endemic plant garden } \\
\text { 10) Explanation of scientific name of plants and how to label plants }\end{array}$ \\
\hline Stage 4 & $11: 25$ to $11: 50$ & $\begin{array}{l}\text { 11) Collecting plant seeds directly and observing seed maturity } \\
\text { 12) Sowing the collected seeds }\end{array}$ \\
\hline Finish & $11: 50$ to $12: 00$ & $\begin{array}{l}\text { 13) Finishing program } \\
\text { 14) Filling out a post questionnaire }\end{array}$ \\
\hline
\end{tabular}

\section{Method of analyzing the educational effects of the program}

To investigate the satisfaction and educational effects of Korea National Arboretum's free semester education program, this study revised and improved the relevant free semester program questionnaire (Korea Forest Service, 2016; National Institute of Ecology, 2014; Lee et al., 2017). The participants responded to the survey twice, once each before and after the program, to examine their satisfaction with the program as well as the educational effects. The pretestposttest questionnaire included certain equivalent items regarding the free semester program and education, while items related to satisfaction in the operation of the program were included only in the posttest questionnaire. The free semester program category included three variables such as career planning, occupational attitude and independence, and the education category included two variables such as awareness of forest biospecies and conservation will, which were used to investigate and analyze the awareness of the participants before and after the program. The items were 
rated on a 5 -point Likert scale ( $1=$ strongly disagree; $2=$ disagree; $3=$ neutral; $4=$ agree; $5=$ strongly agree $)$, and SPSS (Statistical Package for the Social Sciences) ver. 23.0 is used to conduct reliability analysis, descriptive statistics, and paired samples t-test. The survey items are as shown in Tables 6, 7 and 8. The Cronbach's $\alpha$ was higher than .6, and thus the items had suitable reliability.

\section{Results and Discussion}

\section{Program development}

The initial proposal was drawn up in four types such as one-day programs ( 2 hours, 4 hours) and multiple-day programs (three-day, five-day) (Table 1), and the one-day (2 hours) program was used in test operation considering the hours of the Korea National Arboretum free semester program and the travel time of participating students (Tables 2-4). The 'Gardener for a day' program was carried out based on the steps of the ADDIE model: analysis, design, development, implementation, and evaluation. As the tools to enhance efficiency of the program, we developed the 'gardener video' and 'gardener booth' and included them in the program for indirect gardener experience of the participants. The 'gardener video' was 5 minutes long, made based on the job as a gardener at Korea National Arboretum, including actual

Table 5. The general characteristics of the participants $(N=106)$

\begin{tabular}{|c|c|c|c|c|c|}
\hline \multirow{2}{*}{$\begin{array}{l}\text { Location of } \\
\text { middle school }\end{array}$} & \multicolumn{4}{|c|}{ Participants } & \multirow{2}{*}{ Program date } \\
\hline & School year & Gender & Number of participants & Total number & \\
\hline \multirow{2}{*}{ Pocheon-si } & \multirow{2}{*}{$1 \mathrm{st}$} & Male & 24 & \multirow{2}{*}{50} & \multirow{2}{*}{ October 2, 2018} \\
\hline & & Female & 26 & & \\
\hline \multirow{2}{*}{ Namyangju-si } & \multirow{2}{*}{$1 \mathrm{st}$} & Male & 19 & \multirow{2}{*}{56} & \multirow{2}{*}{ October 5, 2018} \\
\hline & & Female & 37 & & \\
\hline
\end{tabular}

Table 6. Questionnaire items and reliability $(N=106)$

\begin{tabular}{|c|c|c|c|c|}
\hline Variable & & Item & $\mathrm{M}^{\mathrm{z}}$ & $\begin{array}{c}\text { Cronbach's } \\
\alpha\end{array}$ \\
\hline \multirow[t]{2}{*}{$\begin{array}{l}\text { In terms of } \\
\text { satisfaction }\end{array}$} & Program & $\begin{array}{l}\text { 1) I was satisfied with the overall content of the program. } \\
\text { 2) While participating in the program, I felt joy and excitement. } \\
\text { 3) I want to participate in other programs at the Korea National Arboretum. } \\
\text { 4) The running time of the program was appropriate. } \\
\text { 5) The number of people per class was appropriate. } \\
\text { 6) I was satisfied with the teaching material. }\end{array}$ & 4.0 & .791 \\
\hline & Instructor & $\begin{array}{l}\text { 7) The teacher communicated well and formed a good rapport with us. } \\
\text { 8) The teacher answered questions faithfully. } \\
\text { 9) The teacher took full advantage of the teaching material. }\end{array}$ & 4.0 & .866 \\
\hline \multirow[t]{2}{*}{$\begin{array}{l}\text { In terms of } \\
\text { free semester } \\
\text { program }\end{array}$} & $\begin{array}{l}\text { Career } \\
\text { interest }\end{array}$ & $\begin{array}{l}\text { 10) I learned about diverse careers related to forest biology. } \\
\text { 11) I want to know more about majors related to biology and forest resources. } \\
\text { 12) I want to study and find a career in forest biology. } \\
\text { 13) Participating in this program has helped me choose my dream and career. }\end{array}$ & 3.9 & .816 \\
\hline & & Total & 4.0 & .880 \\
\hline
\end{tabular}

${ }^{\mathrm{z}}$ 5-point Likert scale answers were used. 
Table 7. An analysis of activity preferences in 'Gardener for a day' program $(\mathrm{N}=106)$

Variable

Item

Frequency (percent)

1) Sowing seeds in a plastic seedling tray

$29(27.4 \%)$

2) Collecting plant seeds

$25(23.6 \%)$

3) Learning about irrigation methods for tropical plants

$20(18.9 \%)$

Preferred activity

4) Visiting a gardener booth

$12(11.3 \%)$

5) Monitoring of the flowering of rare and endermic plants

$11(10.4 \%)$

6) Plant-growing environment survey in a greenhouse

Total

7) It was good to be able to observe the soil and plants and to touch them in person.

8) It was good to experience a gardener's actual work.

Reason to

9) It was good to have a close experience of the nature.

10) It was good to be able to visit the Korea National Arboretum.

Table 8. Pre-post questionnaire comparison analysis $(\mathrm{N}=106)$

\begin{tabular}{|c|c|c|c|c|c|c|}
\hline \multirow[b]{2}{*}{ Variable } & & \multirow[b]{2}{*}{ Item } & \multicolumn{2}{|r|}{ Pre } & \multicolumn{2}{|r|}{ Post } \\
\hline & & & $\mathrm{M}^{\mathrm{z}}$ & $\begin{array}{c}\text { Cronbach's } \\
\alpha\end{array}$ & $\mathrm{M}^{\mathrm{z}}$ & $\begin{array}{c}\text { Cronbach's } \\
\alpha\end{array}$ \\
\hline \multirow{6}{*}{$\begin{array}{l}\text { Free } \\
\text { semester } \\
\text { program }\end{array}$} & \multirow[t]{2}{*}{$\begin{array}{l}\text { Career } \\
\text { planning }\end{array}$} & $\begin{array}{l}\text { 1) Choosing and planning my carer is important. } \\
\text { 2) I need to prepare now for my career. } \\
\text { 3) Think specifically about what to do now to achieve your future hope. } \\
\text { 4) I have my own plan for realizing my dream. } \\
\text { 5) I have a plan to gain various experiences for the future. }\end{array}$ & 3.6 & .842 & 3.8 & .893 \\
\hline & & $\mathrm{p}=.018^{*}$ & & & & \\
\hline & \multirow[t]{2}{*}{$\begin{array}{l}\text { Occupational } \\
\text { attitude }\end{array}$} & $\begin{array}{l}\text { 6) My life could be different depending on what occupation I have. } \\
\text { 7) Any occupation has both its merits and demerits. } \\
\text { 8) Any occupation is difficult but rewarding. }\end{array}$ & 3.7 & .931 & 4.2 & .939 \\
\hline & & $p=.000^{* * * *}$ & & & & \\
\hline & \multirow[t]{2}{*}{ Independence } & $\begin{array}{l}\text { 9) My career is my choice and I am responsible for the consequences. } \\
\text { 10) The career problem (selection of occupation), I try to decide for } \\
\text { myself. } \\
\text { 11) I try to work myself out as much as I can if something rather difficult } \\
\text { happens. }\end{array}$ & 3.9 & .742 & 3.9 & .830 \\
\hline & & $p=.975$ & & & & \\
\hline \multirow{4}{*}{$\begin{array}{l}\text { Forest } \\
\text { education }\end{array}$} & \multirow[t]{2}{*}{$\begin{array}{l}\text { Forest } \\
\text { species } \\
\text { awareness }\end{array}$} & $\begin{array}{l}\text { 12) I like the forest. } \\
\text { 13) Life in the forest is precious. } \\
\text { 14) It is fun to meet and observe living things in person in the forest. } \\
\text { 15) I feel alive when I'm in the woods. }\end{array}$ & 3.3 & .631 & 3.9 & .845 \\
\hline & & $p=.000^{* * *}$ & & & & \\
\hline & \multirow[t]{2}{*}{$\begin{array}{l}\text { Conservation } \\
\text { will }\end{array}$} & $\begin{array}{l}\text { 16) Forest life is something that must coexist with us. } \\
\text { 17) I don't chop flowers and trees recklessly to protect and preserve plants. } \\
\text { 18) The conservation and preservation of forest life (including rare plants) } \\
\text { should be made. }\end{array}$ & 4.1 & .763 & 4.2 & .846 \\
\hline & & $p=.105$ & & & & \\
\hline
\end{tabular}

${ }^{\mathrm{z}} 5$-point Likert scale answers were used.

${ }^{*} p<.05,{ }^{* * *} p<.001$. 
photos of gardeners and brief descriptions. The students were to watch the video before the program to help them understand the program. The 'gardener booth' exhibited the plant growing task that is the most fundamental job of the gardener, as well as the tools used by gardeners to promote understanding about the gardener's job. The students participated in the program in the following order: filling out the pretest questionnaire $\rightarrow$ watching the 'gardener video' $\rightarrow$ visiting the 'gardener booth' $\rightarrow$ meeting and training with the gardener (Tropical plant resources research center) $\rightarrow$ monitoring the blossoming of plants (Rare \& endemic plant garden) $\rightarrow$ collecting plant seeds and seeding $\rightarrow$ filling out the posttest questionnaire. The program was led by the instructor's explanations, and activity sheets were used as training aids to promote students' understanding. At the Tropical plant resources research center, the students met with an actual gardener, listened to the explanation about how to water plants and manage the plant environment, and actually measured the environment in the greenhouse. The students were to perceive the difference in managing various plants by explaining the difference in watering tillandsia and cactus. The students also learned how to control the environment within the greenhouse by being introduced to the low-power integrated environmental measurement device 'Dotori', thereby realizing the importance of environmental control in plant management and promoting understanding about the gardener's job. At the Rare \& endemic plant garden, the students monitored the blossoming of Asteraceae plants that are flowered, through which they could experience the tasks related to the research. They were to also increase their awareness about forest biospecies by explaining about rare and endemic plants. Finally, they actually experienced the tasks of collecting seeds and seeding, thereby encountering the plants in the exhibition gardens closer and actually experiencing the growth method of plants, and could increase their interest in the gardener's job.

The 'Gardener for a day' program that was test-operated was designed to include outdoor training activities such as collecting seeds and seeding, but these activities have limitations due to weather conditions. Thus, a substitute indoor program was also designed to replace the other program in order to increase flexibility of operation (data not shown).

\section{Satisfaction and preference survey results}

As a result of analyzing the satisfaction with the program through the posttest survey of the 'Gardener for a day' program, the mean of each variable was higher than neutral (score 3.0) in both program operation (Score 4.0) and instructor (Score 4.0) (Table 6).

As a result of the preference survey on various missions within the program, 'Sowing seeds in a plastic seedling tray (27.4\%)' showed the highest frequency, followed by 'Collecting plant seeds (23.6\%)', 'Learning about irrigation methods for tropical plants (18.9\%)', 'Visiting a gardener booth (11.3\%)', 'Monitoring of the flowering of rare and endemic plants (10.4\%)', and 'Plant-growing environment survey in a greenhouse (8.5\%) (Table 7). The reason for preference was because they could 'It was good to be able to observe the soil and plants and to touch them in person (33.0\%)', followed by 'It was good to experience a gardener's actual work (31.1\%)', 'It was good to have a close experience of the nature (20.8\%)', and 'It was good to be able to visit the Korea National Arboretum (15.1\%)' (Table 7). The students that participated in the test operation of the program showed high satisfaction because they could gratify their curiosity about the 'gardener' job after the program and also meet their expectations about experiencing the forest, arboreta and plants.

\section{Free semester program and educational aspect analysis results}

As a result of analyzing the educational effects in the three variables 'career planning', 'occupational attitude' and 'independence' in terms of the free semester program through the pretest-posttest questionnaire of the 'Gardener for a day' program, there were significant effects in 'career planning' and 'occupational attitude' (Table 8). This shows that there 
were secondary educational effects for students to reconsider their career paths and dreams and polish up their attitudes toward jobs by giving them the chance to understand and experience the job as a gardener. This result proves that this 'Gardener for a day' program has educational effects in the free semester program because it is a career experience program, even for students who are not interested in forests or gardeners.

As a result of analyzing 'awareness of forest biospecies' and 'preservation will' in terms of education, there were significant educational effects in 'awareness of forest biospecies' (Table 8). The first item of the 'awareness of forest biospecies' category, 'I like forests', showed the greatest mean increase from 3.1 to 3.7 after the program (data not shown). The mean scores all increased in various items of the same category, which suggests that the 'awareness of forest biospecies' increased as students encountered various types of plants such as tropical, rare and endemic plants by participating in the program and indirectly perceived the importance of biospecies during the explanation about the gardener's duties. 'Preservation will' already had a high mean of the three items at 4.1 in the pretest survey and did not show much of a gap between and after the program, thereby not having significance.

\section{Conclusion}

This study developed and test-operated the free semester program job experience program that helps understand Korea National Arboretum and exhibition gardens, learn about gardeners, and directly and indirectly experience their practical affairs. The development steps were based on the ADDIE model, and the program was comprised of watching the gardener video, visiting the booth, meeting with a gardener at Korea National Arboretum, visiting two exhibition gardens, participating in three types of the actual gardener's practical training, and listening to the instructor's explanations. Activity sheets were also used as training aids. After test-operating on 106 students in two middle schools in October 2018, the results and effects of the program were analyzed using the SPSS Statistics ver. 23.0 statistical program. The results are as follows.

First, this study has significance in developing and test-operating the free semester program job experience program based on the tasks and duties of gardeners at Korea National Arboretum, one of the jobs actively engaged in the field by planning, forming, maintaining and managing the exhibition gardens. As a result of the preliminary survey for research, there were two career experience programs for adolescents related to gardeners in 2017-2018 (Yun et al., 2018). Korea National Arboretum's free semester program 'Gardener for a day' program provided students with an opportunity to gain career experience in the field of forestry and learn about gardeners in arboreta and botanical gardens. The Arboretum Education Center of Korea National Arboretum will continue to run programs related to gardeners by developing various related programs and carry out research and publicity about careers and jobs.

Second, the 'Gardener for a day' program contributes to the purpose of the free semester program that helps students find their own dreams and talent, cultivate future-oriented competencies such as creativity, character and sociality, and enjoy a happy school life by enabling students to experience and understand the new job of a gardener and promote awareness about 'perceiving and preserving forest biospecies'. Korea National Arboretum provides education focusing on plants as the source of the ecosystem, and emphasizes education on preserving biodiversity (Yoon et al., 2013). Thus, the program is expected to produce effects that meet the purpose of the free semester program (Korea Educational Development Institute, 2015) that aims to cultivate future-oriented competencies such as creativity and character, in addition to providing career experience.

The following suggestions can be made based on the results. We intend to design and apply various versions of the 'Gardener for a day' program in further research. It is necessary to continuously provide career experience opportunities 
regarding gardeners at arboreta and botanical gardens in order to activate the free semester program and expand the scope of career experience in forestry. To this end, there must be continuous review of the testing tools to investigate the satisfaction and educational effects of the program for analysis and development after applying various versions of the program. Furthermore, we will attempt to operate the 'Gardener for a day' program as a long-term program. Operating this program in the long run will not only help promote understanding about the job as a gardener through continuous experiences but also produce effective results in terms of preserving forest biospecies.

\section{References}

Chollipo Arboretum. 2009. A study on the operation plan for the professional performance of arboretum [Project planning report]. Taean-gun, Korea: Author.

Jeong, M.N. 2013. Activation of arboretum/botanical gardens in Korea through characterization survey on theme gardens, visitors and gardeners: Focused on the private arboretum and botanical garden registered at the forestry administration. Master's thesis, Konkuk University, Seoul, Korea.

Kang, S.Y. 2013. The progress development for reinforcing creative research competence university student. Master's thesis, Sookmyung Women's University, Seoul, Korea.

Kim, A.R. and A.M. Kim. 2018. How an innovative school implements the free year program: The case of K middle school. J. Educ. Cult. [Inha University] 24(5):499-523. https://doi.org/10.24159/joec.2018.24.5.499

Kim, O.K. 2011. A study on the education program for professional gardener. Master's thesis, Hankyong National University, Gyeonggi-do, Korea.

Korea Educational Development Institute. 2015. A study on improvement of operation of free semester: Focusing on the connection with general term. Jincheon, Korea: Author.

Korea Forest Service. 2016. Free semester. Daejeon, Korea: Author.

Korea Forest Service. 2018. Second comprehensive plan for forest education (2018-2022). Daejeon, Korea: Author.

Korea National Arboretum. 2004. Development of training management system and program. Pocheon-si, Korea: Author.

Korea National Arboretum. 2019. Korea National Arboretum map. Pocheon-si, Korea: Author.

Lee, H.S. 2018, January 8. Free school semester system career exploration activity in Seoul city strategy for revitalization (Project report 243). Seoul, Korea: The Seoul Institute.

Lee, J.Y., I.H. Kim, J.I. Jeon, S.J. Jung, J.N. Gwak, S.A. Song, and H.S. Kwon. 2008. Development and application of the framework for analyzing forest education paradigms. Environ. Educ. 21(1):31-44.

Lee, S.H., S.Y. Lee, B.G. Jeoun, and M.J. Yoon. 2017. Development and implementation of free semester program in arboreta and botanic gardens -Focusing on Korea National Arboretum 'I am a one-day entomologist' program-. J. Korean Inst. For. Recreat. 21(1):49-57. https://doi.org/10.34272/forest.2017.21.1.005

National Institute of Ecology. 2014. Participant's satisfaction survey of free semester ecological education program. Seocheon, Korea: Author.

Seok, H.D. and S.J. Ahn. 2013, July 10. Policy direction of forest environment service for the welfare of the people. Agricultural Policy Focus [Korea Rural Economic Institute] 63:1-16.

Yoon, J.W., S.K. Kang, J.O. Hyun, Y.S. Kim, U.S. Song, Y.J. Lim, H.T. Shin, G.S. Kim, J.W. Sung, K.H. Park, C.H. Lee, and M.H. Yi. 2013. The status of arboreta's education programs focused on plant diversity conservation in Korea and Foreign nations. J. Korean Inst. For. Recreat. 17(2):49-54.

Yun, D.L., J.G. Bae, and M.J. Yoon. 2018, June. Development of free semester system education program in arboreta and botanic gardens -Focusing on Korea National Arboretum 'One Day Gardener' program-. Proceedings of the first half of 2018 Symposium of the Korean Society for Environmental Education (pp. 200-204). Cheongju University, Korea. 